\title{
Determination of genetic divergence in some bread wheat varieties by IRAP and ISSR analyses
}

\author{
Zekiye Budak BAŞÇiFTÇi I ${ }^{1}$, Murat OLGUN ${ }^{1}$, Serap SUNAR ${ }^{* 2}$, Nalan Yildirim DOĞAN ${ }^{3}$, N. Gözde AYTER ${ }^{1}$, \\ Guleray AGAR ${ }^{4}$ \\ ORCID: 0000-0002-4034-2537; 0000-0001-6981-4545; 0000-0002-2011-1117; 0000-0002-5344-5367; \\ 0000-0002-5121-4303; 0000-0002-8445-5082
}

\author{
${ }^{1}$ Eskişehir Osmangazi University, Faculty of Agriculture, Eskişehir, Turkey. \\ ${ }^{2}$ Erzincan University, Faculty of Pharmacy, Department of Pharmaceutical Botany, Erzincan 24000, Turkey. \\ ${ }^{3}$ Department of Biology, Faculty of Science, Erzincan University, Erzincan, Turkey \\ ${ }^{4}$ Department of Biology, Faculty of Science, Ataturk University, Erzurum, Turkey
}

\begin{abstract}
In this study, it was aimed to detect the differences of genotypes through the measurement of genetic distance in bread wheat (Triticum aestivum L.) genotypes. The genetic diversity of 12 bread wheat genotypes (Bozkır, Harmankaya 99, Altay 2000, Yıldırım, Bezostaja 1, Ahmetağa, Müfitbey, Aldane, Es 26, Alperbey, Atay 85 ad Eraybey) was examined through ISSR and IRAP techniques. As fast molecular techniques, ISSR and IRAP methods can be effectively included in breeding programs both for genetic exploration and evaluation and for the protection of elite breeding and production materials. 12 genotypes were classified into two main clusters in the dendrogram produced by using the ISSR and IRAP markers. While Cluster I included Bozkır, Harmankaya 99, Altay 2000 and Yıldırım, cluster II included Bezostaja 1, Ahmetağa, Müfitbey, Aldane, Es 26, Alperbey, Atay 85 and Eraybey. Furthermore, the results obtained in this study indicated that ISSR and IRAP methods were effective for the definition of bread wheat genotypes.
\end{abstract}

Keywords: bread wheat genotypes, genetic difference, IRAP, ISSR

\section{Bazı ekmeklik buğday çeşitlerinin IRAP ve ISSR analizleri ile genetik farklılı̆̆nın belirlenmesi}

\section{Özet}

$\mathrm{Bu}$ çalışmada ekmeklik buğday (Triticum aestivum L.) genotiplerinde genetik uzaklık ölçümü yapılarak genotip farklılıklarının tespiti amaçlanmıştır. 12 ekmeklik buğday genotipinin (Bozkır, Harmankaya 99, Altay 2000, Yıldırım, Bezostaja 1, Ahmetağa, Müfitbey, Aldane, Es 26, Alperbey, Atay 85 ad Eraybey) genetik çeşitliliği ISSR ve IRAP teknikleri ile incelenmiştir. ISSR ve IRAP yöntemleri, hem genetik inceleme ve değerlendirme hem de elit yetiştirme ve üretim materyallerinin korunması için sslah programlarına etkin bir şekilde dahil edilebilir. ISSR ve IRAP belirteçleri kullanılarak üretilen dendrogramda 12 genotip iki ana küme halinde sınıflanmıștır. İlk küme Bozkır, Harmankaya 99, Altay 2000 ve Yıldırım’ı içerirken, ikinci küme Bezostaja 1, Ahmetağa, Müfitbey, Aldane, Es 26, Alperbey, Atay 85 ve Eraybey'i içermektedir. Ayrıca bu çalışmadan elde edilen sonuçlar ISSR ve IRAP yöntemlerinin ekmeklik buğday genotiplerinin tanımlanmasında etkin olduğunu göstermiştir.

Anahtar kelimeler: ekmeklik buğday genotipleri, genetik farklılık, IRAP, ISSR

\footnotetext{
${ }^{*}$ Corresponding author / Haberleşmeden sorumlu yazar: Tel.: +904462245344; Fax.: +904462245343; E-mail: ssunar@erzincan.edu.tr

(C) Copyright 2021 by Biological Diversity and Conservation $\quad$ Received: 02.11.2020; Published: 15.04.2021 


\section{Introduction}

The request for grain exports is also growing because of increased prosperity and the increase in world population. Nevertheless, the requirement for feed grains and the request for future energy production are in tendency to enhance domestic demand. To get more products from the existing regions is the best way to acquire the desired increase in production[1].

In the world, wheat is the main source of nutrient. It is predicted that there would be 773 million ton of production in 2020/21 (FAO 2020/21). For nutritional requirements, it is necessary that increased population should increase in wheat production. the adverse effect of drought and high temperatureon a crop can be minimized by avoiding stress at the most sen-sitive stages of crop development such as reproductive andgrain-filling periods [2, 3]. Genotype $\mathrm{x}$ environment interactions $(\mathrm{G} \times \mathrm{E})$, which alter the rankings of genotypes from site to site and from season to season, have restricted the rate of genetic advance for the areas in such environments $[4,5,1,6]$. New wheat cultivars are improved by breeders with the aim of increasing total production. Besides, the yield performances of these new cultivars are tested in different places. The success of a new wheat variety is based on its yield and adaptation potential in those places [7].

Genetic diversity has an essential role in the success of crop breeding programs and new cultivar improvement. Knowledge of genetic diversity has been successfully employed for efficient germplasm management and utilization, genetic fingerprinting and genotype selection, novel biotechnological methods have been efficiently employed in genotypic differences of genotypes $[8,9,10]$. In this study, it was aimed to detect the differences of genotypes through the measurement of genetic distance in bread wheat genotypes and to show the usability of chromosome mapping for different aims such as breeding programs, elite seed productions [11, 12].

\section{Materials and methods}

This study was conducted at Osmangazi University Agriculture College Eskişehir experimental station during the 2015-2016 crop growing season( $36^{\circ} 56^{\circ}$ North, 30 $32^{\circ}$ East, $788 \mathrm{~m}$ altitude). 12 bread wheat genotypes (Bozkir, Harmankaya 99, Altay 2000, Yıldırım, Bezostaja 1, Ahmetağa, Müfitbey, Aldane, Es 26, Alperbey, Atay 85 ad Eraybey) were used in this study. The precipitation in 2015-2016 and long term years (1965-2016) was 342.1 mm and $322.6 \mathrm{~mm}$, respectively. Moreover, minimum, maximum and average temperatures were found to be $-3.8^{\circ} \mathrm{C}, 32.4^{\circ} \mathrm{C}$, $8.4{ }^{\circ} \mathrm{C}$; $-9.4{ }^{\circ} \mathrm{C}, 28.4{ }^{\circ} \mathrm{C}, 7.9^{\circ} \mathrm{C}$ for prolonged years in years $2015-2016$. The soil properties in the experimental area were $301.7 \mathrm{mmol} / \mathrm{kg}$ in $\mathrm{P}_{2} \mathrm{O}_{5}, 357.4 \mathrm{mmol} / \mathrm{kg}$ in $\mathrm{K}_{2} \mathrm{O}, 1.05 \%$ in $\mathrm{CaCO}_{3}$, and $2.02 \%$ in organic matter, 6.04 in $\mathrm{pH}$, and $1.89 \mathrm{dS} / \mathrm{m}$ in electrical conductivity. We conducted experiments with three replications in random block design. Bread wheat genotypes were planted on the $15^{\text {th }}$ of September with $475 \mathrm{seed} / \mathrm{m}^{2}$ rate. The plot had dimensions of $6 \mathrm{~m} / 1.2 \mathrm{~m}$ $\left(7.2 \mathrm{~m}^{2}\right)$. Sixty $\mathrm{kg} \mathrm{N} \mathrm{ha}^{-1}\left(1 / 2\right.$ at sowing period and $1 / 2$ at tillering period) and $60 \mathrm{~kg} \mathrm{ha}-1 \mathrm{P}_{2} \mathrm{O}_{5}$ (at sowing) were administered. In this study, superphosphate $\left(46 \% \mathrm{P}_{2} \mathrm{O}_{5}\right)$ and ammonium sulfate $(21 \% \mathrm{~N})$ were used as fertilizer. Genotypes were collected on the $10^{\text {th }}$ of July, and the seeds of the genotypes were kept for analysis.

\subsection{Isolation of $g D N A$}

The Qiagen DNA extraction kit (Qiagen, Hilden, Germany) was used to get the extract of genomic DNA (gDNA) from the powdered leaf materials, by following the manufacturer's directives. gDNA samples loading into agarose gel $1 \%(\mathrm{w} / \mathrm{v})$ in $0.5 \times \mathrm{xBE}$ (Tris-Borate- EDTA) buffer at $70 \mathrm{~V}$ was performed for 150 minutes. In order to check the quality and quantity of the amplified DNA products, a spectrophotometer (Qiagen, Qiaxpert Instrument, Germany) was used. Pure of sample DNA was used in ISSR and IRAP marker techniques.

\subsection{IRAP amplification}

As it is seen in Table 1, 10 primers had been used for the generation of IRAP profiles. A Bio-Rad thermocycler (Bio-Rad Laboratories Inc., Hercules, CA, USA) was used to perform PCR amplifications. The reaction mixtures (20 $\mu \mathrm{l})$ were fixed as described below: $45 \mathrm{ng}$ of $\mathrm{g}$ DNA, $1 \times$ buffer $(10 \mathrm{mM}$ Tris-HCl, $50 \mathrm{mM} \mathrm{KCl}, \mathrm{pH}=8.3), 1.5 \mathrm{mM}$ of magnesium chloride, $0.2 \mu \mathrm{M}$ of each dNTP, $0.5 \mathrm{U}$ of Taq polymerase (Cinagen Co., Iran) and 10 pmol of each primer were added.

The PCR program for the IRAP was as the following: an initial denaturation $5 \mathrm{~min}$ at the temperature of $94^{\circ} \mathrm{C}$, 35 cycles of $45 \mathrm{~s}$ at the temperature of $95^{\circ} \mathrm{C}, 40 \mathrm{~s}$ at the temperature of $55^{\circ} \mathrm{C}$ to $63^{\circ} \mathrm{C}$ (Table 1 ), 2 min at the temperature of $72^{\circ} \mathrm{C}$, followed by a final extension of $5 \mathrm{~min}$ at the temperature of $72^{\circ} \mathrm{C}$.

\subsection{ISSR amplification}

26 oligonucleotide primers were tested for ISSR amplifications, among which 12 primers were selected and used for future studies (Table 1). The PCR mixture $(25 \mu \mathrm{l})$ was prepared as the following: $40 \mathrm{ng}$ of template DNA, $10 \mathrm{x}$ 
buffer, $200 \mathrm{Mm}$ of each of the four dNTPs, $1 \mathrm{U}$ of Taq DNA polymerase, $0.5 \mathrm{mM}$ of primer and $1.5 \mathrm{mM} \mathrm{MgCl}_{2}$. Amplification was performed in a thermal cycler programmed for an initial denaturation at a temperature of $94^{\circ} \mathrm{C}$ for the period of $5 \mathrm{~min}$ followed with the following 35 cycles of $45 \mathrm{~s}$ at the temperature of $94^{\circ} \mathrm{C}, 1 \mathrm{~min}$ at the annealing temperature and $1 \mathrm{~min}$ at the temperature of $72^{\circ} \mathrm{C}$, ends with a final extension stage of 7 min at the temperature of $72^{\circ} \mathrm{C}$.

\subsection{Electrophoresis}

The PCR products ( $27 \mathrm{ml}$ ) were blended with $6 \mathrm{X}$ gel loading buffer ( $3 \mathrm{ml}$ ) and exposed to agarose. The electrophoresis was then applied to separate them via $1.5 \%$ agarose gel $(1.5 \% \mathrm{w} / \mathrm{v})$ in $0.5 \mathrm{xTBE}$ buffer (Tris-BorateEDTA) with was performed $70 \mathrm{~V}$ for the period of $150 \mathrm{~min}$. Ethidium bromide solution $(2 \mu \mathrm{l}$ Etbr/100ml $1 \mathrm{xTBE}$ buffer) was used to stain the gel for $40 \mathrm{~min}$, and The Bio Doc Image Analysis System with Uvi-soft analysis package (Cambridge, UK) was used to determine the amplified DNA products.

\subsection{Analysis}

The TotalLab TL120 computer software program was used to evaluate the ISSR and IRAP bands. The scoring of PCR products was conducted as the presence (1) and absence (0) of band for all genotypes, and their analysis was performed. After the Jaccard (1908) similarity index was calculated using the data, the construction of a dendrogram was conducted based upon the relevant matrix with the UPGMA (unweighted pair group method using arithmetic average) technique..

\section{Results}

\subsection{IRAP and ISSR analysis}

The results of our IRAP and ISSR analysis are presented in Table 1. Ten IRAP primers revealed specific and stable results in wheat genome (Table 1).

A total of 92 bands, $86.9 \%$ of which were polymorphic, were produced by ten IRAP primers. The percentage of polymorphic bands that were produced by each primer ranged from $66.6 \%$ to $100 \%$. While the primer Copiar provided the highest number of bands (14), the Sukkula primer provided the lowest number of bands (6). The band sizes of the primers used were $15-25 \mathrm{bp}$.

Table1. Details of banding pattern revealed through IRAP and ISSR primers. $(\mathrm{R}=\mathrm{A}, \mathrm{G} ; \mathrm{Y}=\mathrm{C}, \mathrm{T})$

\begin{tabular}{|c|c|c|c|c|c|c|}
\hline Mar-kers & $\begin{array}{l}\text { Primer/primer } \\
\text { Combination }\end{array}$ & Sequence (5'-3') & $\begin{array}{l}\text { Length of } \\
\text { amplified } \\
\text { bands } \\
\end{array}$ & $\begin{array}{l}\text { No of } \\
\text { bands }\end{array}$ & $\begin{array}{l}\text { No } \\
\text { polymorphic } \\
\text { bands }\end{array}$ & $\begin{array}{l}\text { Polymorphism } \\
\text { ratio }(\%)\end{array}$ \\
\hline \multirow[t]{11}{*}{ IRAP } & Nikita & CGCATTTGTTCAAGCCTAAACC & $500-1900$ & 12 & 10 & 83.3 \\
\hline & LTR6150 & CTGGTTCGGCCCATGTCTATGTATCCACACATGTA & $250-1700$ & 9 & 8 & 88.8 \\
\hline & 3' LTR & TGTTTCCCATGCGACGTTCCCCAACA & $750-2300$ & 8 & 8 & 100 \\
\hline & Sukkula & GATAGGGTCGCATCTTGGGCGTGAC & $500-1700$ & 6 & 4 & 66.6 \\
\hline & Copiar & TTG AAC CCC TTT TGA TGT AT & $300-2000$ & 14 & 12 & 85.7 \\
\hline & Stowaway & CTTATATTTAGGAACGGAGGGAGT & $250-1500$ & 8 & 7 & 87.5 \\
\hline & 5' LTR1 & TTGCCTCTAGGGCATATTTCCAACA & $500-2400$ & 9 & 7 & 77.7 \\
\hline & 5' LTR2 & ATCATTCCCTCTAGGGCATAATTC & $250-1900$ & 8 & 8 & 100 \\
\hline & WLTR2105 & ACTCCATAGATGGATCTTGGTGA & $600-1800$ & 7 & 6 & 85.7 \\
\hline & LTR6149 & CTCGCTCGCCCACTACATCAACCGCGTTTATT & $400-2200$ & 11 & 10 & 90.9 \\
\hline & Total & & $250-2400$ & 92 & 80 & 86.9 \\
\hline \multirow[t]{13}{*}{ ISSR } & ISR1 & $(\mathrm{CA})_{8} \mathrm{G}$ & $500-1900$ & 10 & 8 & 80 \\
\hline & ISR2 & $(\mathrm{AC})_{8} \mathrm{AT}$ & $300-2600$ & 14 & 12 & 85.7 \\
\hline & ISR3 & $(\mathrm{AC})_{8} \mathrm{G}$ & $750-2100$ & 8 & 7 & 87.5 \\
\hline & ISR4 & $(\mathrm{AG})_{8} \mathrm{GC}$ & $300-1800$ & 6 & 4 & 66.6 \\
\hline & ISR5 & $(\mathrm{AG})_{8} \mathrm{YA}$ & $400-2400$ & 9 & 8 & 88.8 \\
\hline & ISR6 & $(\mathrm{AG})_{8} \mathrm{TA}$ & 500- 1900 & 8 & 6 & 75 \\
\hline & ISR7 & $(\mathrm{GA})_{8} \mathrm{YT}$ & $300-2750$ & 12 & 10 & 83.3 \\
\hline & ISR8 & $(\mathrm{AG})_{8} \mathrm{YT}$ & $500-1600$ & 5 & 4 & 80 \\
\hline & ISR9 & $(\mathrm{CT}) 8 \mathrm{~T}$ & $600-2000$ & 13 & 11 & 84.6 \\
\hline & ISR10 & (GT)8C & $750-1500$ & 8 & 8 & 100 \\
\hline & ISR11 & (GA)8T & $500-1200$ & 12 & 11 & 91.6 \\
\hline & ISR12 & (GA)8C & $300-1800$ & 10 & 8 & 80 \\
\hline & Total & & $300-2750$ & 115 & 97 & 84.3 \\
\hline
\end{tabular}

Twelve ISSR primers combinations were utilized for the analysis of genetic diversity in 12 wheat genotypes. As it can be seen in the table, a total of 115 scorable amplification products, 97 of which were polymorphic bands, 
ranged from 300 to $2750 \mathrm{bp}$. Ratio polymorphism was found to be $84.3 \%$. While the highest number of bands was acquired from primer ISR2 ( $14 \mathrm{bands}$ ), the lowest number of bands was acquired from ISR8 (5 bands). A combination of data from the IRAP and ISSR markers were used for the construction of the UPGMA dendrogram (Figure 1 ). 12 wheat genotypes were classified into 2 main clusters. While Cluster I included Bozkır, Harmankaya 99, Altay 2000, Yıldırım, , cluster II included Bezostaja -1, Ahmetağa, Müfitbey, Aldane, ES-26, Alperbey, Atay 85, Eraybey. While the greatest similarity was found between genotype Bozkır and Harmankaya 99 (0.113), the greatest dissimilarity was found between Bozkir and Eraybey (0. 892).

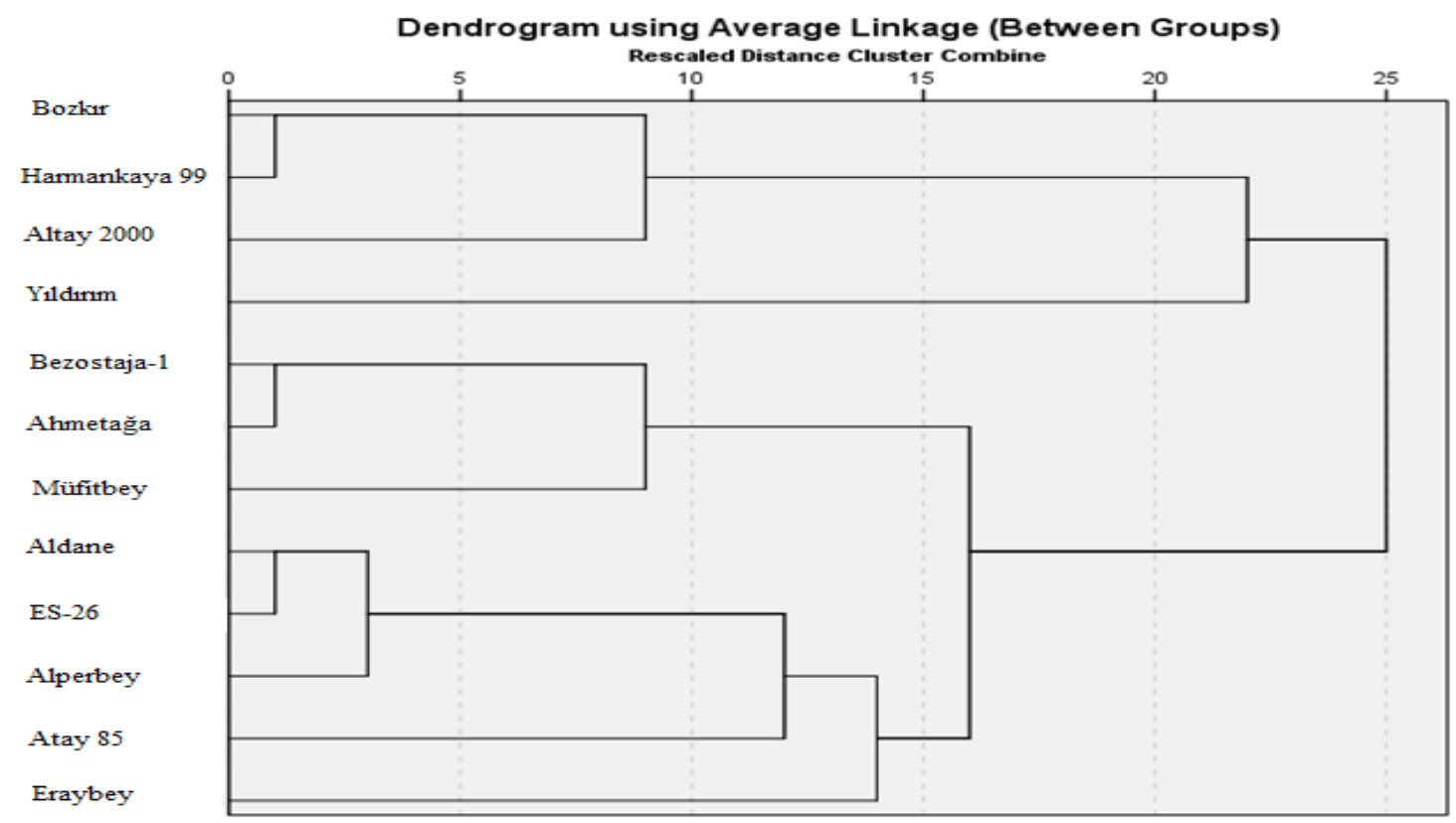

Figure 1. UPGMA clustering for 12 wheat genotypes based on IRAP and ISSR markers.

\section{Conclusions and discussion}

The genotypes used in the study were improved as a result of long breeding studies, and each of them had different genetic characteristics/genetic capacity. Furthermore, each of them had a different capability to respond to biotic and abiotic stresses. These varieties are utilized as witness/control varieties in breeding studies and other scientific studies. Furthermore, these genotypes are also used as witness/control genotypes in breeding programs and other scientific studies. For instance, some genotypes have more resistance to yellow rust compared to others. Another one is more resistant to drought. Working with genotypes having different genetic characteristics/capacities refers to working with a wider genetic variation. Thus, to reveal their genetic similarity and the demonstration of this phenomena will help genetic progress in future breeding programs.

Retrotransposon-based molecular markers containing IRAP and REMAP have been used to examine genetic diversity in bread wheat (Triticum aestivum L.). Retrotransposon sequences, between plant families can be easily used across species lines, among intimately related genera, and even sometimes between plant families [13, 14].

ISSR profiles were utilized to examine intra-specific genetic diversity analysis in many bread wheat genotypes [15]. They were successfully utilized for the prediction of genetic diversity in main crops such as maize [16], wheat [17], rice [18], barley [19] and cotton [20] It was reported by Carvalho et al. [21] that ISSR markers provided great potential for differentiating closely related wheat cultivars and botanical varieties and allowed for the determination of higher levels of polymorphism.

According to the similarity matrix (Fig. 1) Bozkır, Harmankaya 99; Bezostaja 1, Ahmetağa and Müfitbey; Aldane, Es 26, Alperbey and Atay 85 were determined to be close related varieties; furthermore, distant related varieties were Bozkir and Eraybey. Wide differences in genetic characteristics in bread wheat genotypes may enable to develop novel promising genotypes in germplasms of crop programs. The results indicated that IRAP and ISSR analyses were useful for the differentiation of the bread wheat genotypes tested in this study.

Wheat, which is the most consumed, cultured and most preferred plant of the world, will continue to be the plant that mostly occupies the agenda on production and breeding programs in the future.

To meet the food needs, that will rapidly increase in the future, can be achieved with the development of plants that are highly efficient, high quality, stable and resistant to stress. Such a goal is only achieved by effective and successfully implemented breeding programs with vast genotypic variation. 


\section{References}

[1] Christopher, J.T., Manschadi, A.M., Hammer, G.L., Borrell, A.K. (2008). Developmental and physiological traits associated with high yield mand stay-green phenotype in wheat. Australian J Agric Res, 59,354-364.

[2] Saini, H.S., Westgate, M.E., 2000. Reproductive development in graincrops during drought. Adv. Agron. 68, 5996.

[3] Hossain, A., Lozovskaya, M.V., Zvolinsky, V.P., Tutuma, N.V., (2012a). Effect of soil resources and climatic factors (temperature) onspring wheat and barley in the northern Bangladesh and southern Russia. Paper presented in "International scientific and practicalconference on problems of environmental management and con-servation of ecological balance in the arid zones", held in "CaspianScientific Research Institute of Arid Agriculture', Salt Zaymische,Chorniarsky district, Astrakhan State, Russia, from 16-18 May,2012.

[4] Cooper, M., Woodruff, D.R., Phillips, I.G., Basford, K.E., Gilmour, A.R. (2001). Genotype-by-management interactions for grain yield and grain protein concentration of wheat. Field Crops Res, 69, 47-67.

[5] Richards, R.A., Rebetzke, G.J., Condon, A.G., Herwaarden, A.F. (2002). Breeding opportunities for increasing the efficiency of water use and crop yield in temperate cereals. Crop Sci, 42, 111-121.

[6] Kaya,Y., Palta, Ç., Taner, S. (2002). Additive Main Effects and Multiplicative Interactions Analysis of Yield Performances in Bread Wheat Genotypes across Environments. Türk J Agric Fort, 26, 275-279.

[7] Boubakar, M., Hammouda, M.B., Sakouhi, L. (1999). Adaptation and Yield Stability of Three Cereal Species in Semi-arid and Sub-humid Regions of Tunusia. Secheresse, 10(4), 273-279.

[8] FAO (1998) .The States of the World's Plant Genetic Resources for Food and Agriculture p 510 FAO Rome Italy.

[9] Huang, X.Q., Börner, A., Röder, M.S., Ganal, M.W. (2002). Assessing genetic diversity of wheat (Triticumaestivum L.) germplasm using microsatellite markers. Theor Appl Genet,105, 699-707.

[10] Engles, J.M.M., Rao, V.R., Brown, A.H.D. \& Jackson, M.T. (2002). Managing Plant Genetic Diversity. p 48, CABI Publishing UK.

[11] Carvalho, A., Guedes-Pinto, H., Martins-Lopes, P., Lima-Brito, J. (2010). Genetic variability of Old Portuguese bread wheat cultivars assayed by IRAP and REMAP markers. Annals of App biology, 156(3), 337-345.

[12] Nasri, S., Abdollahi Mandoulakani, B., Darvishzadeh, R., Bernousi, I. (2013). Retrotransposon Insertional Polymorphism in Iranian Bread Wheat Cultivars and Breeding Lines Revealed by IRAP and REMAP Markers. Biochemical Genetics, 51(11-12), 927-943.

[13] Kalendar, R., Flavell, A.J., Ellis, T.H.N., Sjakste, T., Moisy, C. (2011). Analysis of plant diversity with retrotransposonbased molecular markers. Heredity, 106, 520-530.

[14] Lou, Q., Chen, J. (2007). Ty1-copia retrotransposon-based SSAP marker development and its potential in the genetic study of cucurbits. Genome, 50, 802-810.

[15] Giancarla, V., Emilian, M., Radu, S., Sorin, C., Sorina, P., Cerasela, P. (2012). The use of RAPD and ISSR markers for genetic diversity among some barley cultivars. Rom Biotechnol Lett, 17(4), 7493-7503.

[16] Kantety, R.V., Zeng, X.P., Bennetzen, J.L. and Zehr, B.E.(1995). Assesment of genetic diversity in dent and popcorn (Zea mays L.) inbred lines using inter simple sequence repeat (ISSR) amplification. Mol Breeding,1, 365-73.

[17] Nagoaka, T. and Ogihara, Y.(1997). Applicability of inter- simple sequence repeat polymorphisms in wheat for use as DNA markers in comparison to RFLP and RAPD markers. Theor Appl Genet, 94, 597-602.

[18] Blair, M.W., Panaud, O. and Mc Couch, S.R.(1999). Inter- simple sequence repeat (ISSR) amplification for analysis of micro-satellite motif frequency and fingerprinting in rice (Oryza sativa L.). Theor Appl Genet,98, 780-92.

[19] Hou, Y.C., Yan, Z.H., Wei, Y.M. and Zheng, Y.l.(2005). Genetic diversity ib barley from west China based on RAPD and ISSR analysis. Barley Genetic Newsletter,35, 9-12.

[20] Şahin, C.B., İşler, N., Rustamova, V.(2020), Bazı Pamuk Çeşitlerinin ISSR Markörleri İle Karakterizasyonu. Kahramanmaraş Sütçü Imam Üniversitesi Tarım ve Doğa Dergisi, 23, 108-116.

[21] Carvalho, A., Lima-Brito, J., Maçãs, B. \& Guedes-Pinto, H.(2009). Genetic diversity and variation among botanical varieties of old Portuguese wheat cultivars revealed by ISSR assays. Biochemical Genetics, 47(3-4), 276-294. 